\title{
Epidemiology and Control of Mango Bacterial Black Spot
}

\section{Mango Production}

Mango (Mangifera indica L.) fruit, which ranks fifth in production worldwide, is cultivated throughout the tropics as well as in subtropical areas such as Spain, Florida, North Africa, Israel, and Japan (39). The countries that are the largest producers are India, China, Mexico, Thailand, Pakistan, and the Philippines, with almost $80 \%$ of the world production (Table 1). The export trade of mango amounts to almost U.S. $\$ 400$ million and is dominated by Mexico (Table 2).

Mango bacterial black spot (MBBS) is very difficult to control, and it usually becomes a limiting factor for mango industries when fungal diseases and other pests can be managed at acceptable levels. MBBS can be very destructive in areas where high temperatures and rainfalls occur concomitantly. A bacterial disease caused by Pseudomonas syringae pv. syringae shows apical necrosis but no symptoms on fruits $(10,38)$. This disease was reported in areas where low temperature and high humidity occur simultaneously (Spain, Florida, and Israel). Another disease associated with an erwinia-like bacterium has been reported in Central America $(22,23,36)$. Several major fungal diseases of mango are anthracnose caused by Colletotrichum gloeosporioides (Penz.) Penz. \& Sacc. in Penz., powdery mildew caused by Oidium mangiferae (Berthet), and black rot caused by Alternaria alternata (Fr.:Fr.) Keissl. However, integrated control strategies are available for controlling these fungal diseases $(7,12,41)$.

Dr. Pruvost's address is: Laboratoire de Phytopathologie, CIRAD 3P, 7 ch de l'IRAT, 97410 SAINT-PIERRE, Ile de la Réunion, France.

Fax: (262) 262357641.

E-mail: olivier.pruvost@cirad.fr

Publication no. D-2001-0706-01F

(c) 2001 The American Phytopathological Society

\section{Bacterial Black Spot}

Doidge initially described bacterial black spot in South Africa in 1909 (13). The disease has since been found in Australia (37), the Comoro Islands (44), India (40), Japan (16), Kenya (9), Malaysia (31), Mauritius (44), New Caledonia (44), Pakistan (1), the Philippines (44), Réunion (11), Taiwan (5), Thailand (44), and the

Table 1. World mango production in 2000 (6)

\begin{tabular}{lrr}
\hline Country & Production $(\mathbf{t})$ & \multicolumn{1}{c}{$\%$} \\
\hline India & $12,000,000$ & 49.0 \\
China & $2,561,522$ & 10.5 \\
Mexico & $1,529,307$ & 6.2 \\
Thailand & $1,250,000$ & 5.1 \\
Pakistan & 937,705 & 3.8 \\
Philippines & 931,500 & 3.8 \\
Indonesia & 801,777 & 3.3 \\
Nigeria & 729,000 & 3.0 \\
Others & $3,753,533$ & 15.3 \\
World & $24,494,344$ & 100 \\
\hline
\end{tabular}

United Arab Emirates (15). It is probably present throughout southern and eastern Africa as well as in most parts of Asia (Fig. 1). It has not been reported in western and northern Africa, and the only reported occurrence of the disease in the Americas was in Brazil in the 1950s (53).

Table 2. Mango export trade in 1999 (excluding countries that export but do not produce mango) (6)

\begin{tabular}{lrr}
\hline Country & Export $(\mathbf{t})$ & \multicolumn{1}{c}{$\%$} \\
\hline Mexico & 204,002 & 39.4 \\
Brazil & 53,765 & 10.4 \\
India & 47,149 & 9.1 \\
Pakistan & 37,971 & 7.3 \\
Philippines & 35,102 & 6.8 \\
Peru & 20,026 & 3.9 \\
Ecuador & 15,668 & 3.0 \\
South Africa & 12,341 & 2.4 \\
Others & 91,145 & 17.6 \\
World & 517,169 & 100 \\
\hline
\end{tabular}

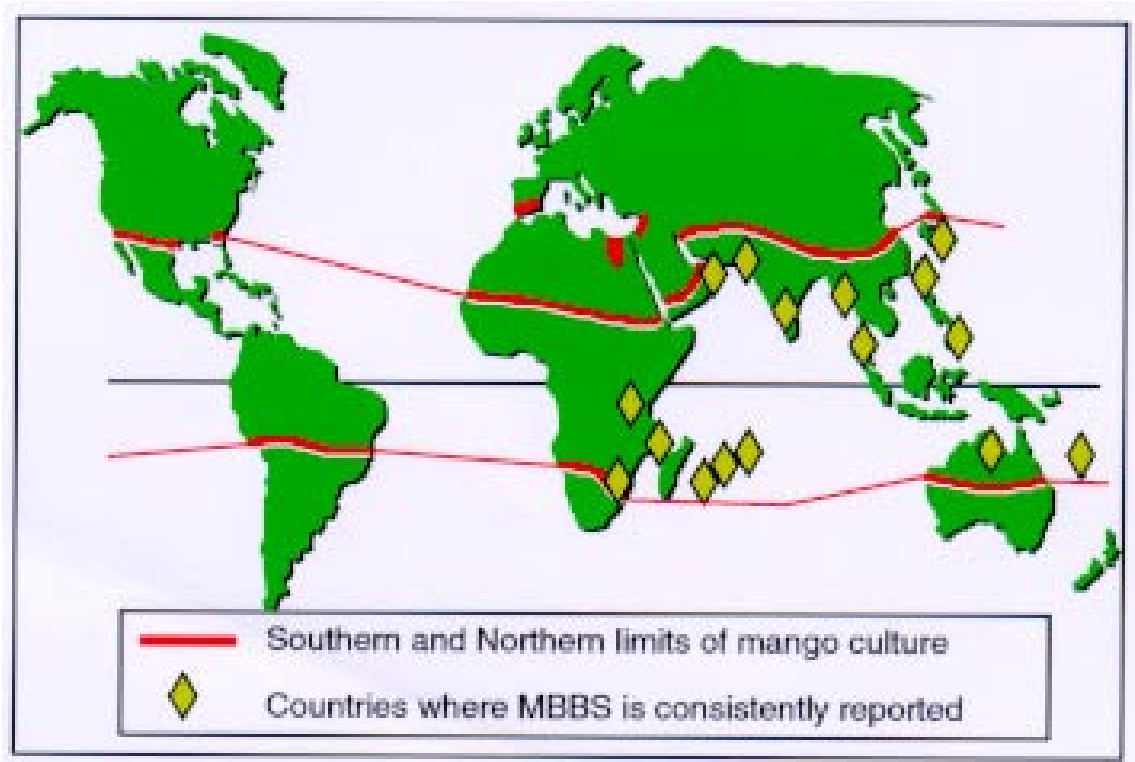

Fig. 1. World distribution of mango bacterial black spot. 


\section{Economic Importance}

Many commercial cultivars are highly susceptible to MBBS, and infections can result in drastic yield losses associated with premature fruit drop, reduction of fruit quality, and induction of severe defoliation, especially when storms or hurricanes are involved. From 50 to $80 \%$ fruit infection is common on very susceptible cultivars $(27,42)$. MBBS is a major concern in the export market, where high fruit quality is required. In 1996 and 1997, severe MBBS epidemics occurred in most of the mango producing areas of South Africa, causing almost $100 \%$ fruit loss on the most susceptible cultivars because of fruit drop and nonmarketability of the fruit. The estimated loss to MBBS alone in 1996 was 5 million Rands (approximately U.S. \$1 million).

\section{Symptoms}

MBBS affects all aerial parts of the mango plant. The bacterial pathogen can infect through wounds and natural open-
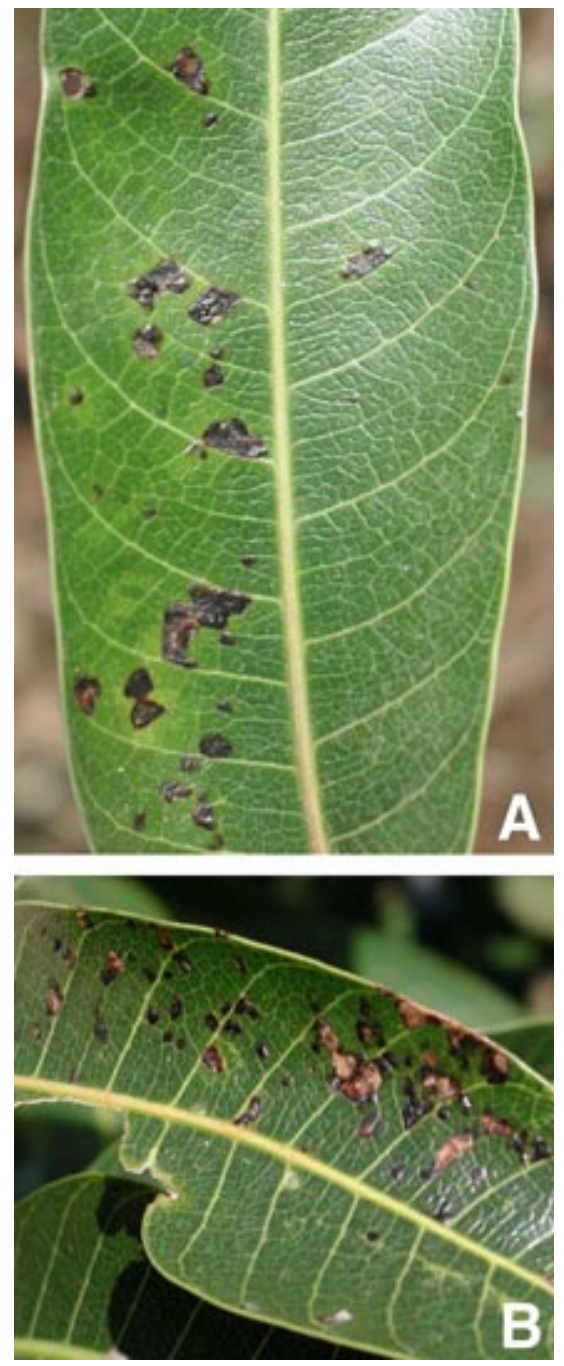

Fig. 2. Black spots on leaves. A, Young symptoms (approximately 2 months old). B, Old lesions (several months old). ings. Leaf and fruit symptoms are most common, but twig and branch cankers may occur when infection is severe (i.e., on highly susceptible cultivars). Leaf symptoms begin as small water-soaked spots delineated by veins, becoming raised, black, sometimes with a chlorotic halo (Fig. 2A). Microscopically, bacteria induce hypertrophy of leaf tissue as a result of enlargement of intercellular spaces of spongy parenchyma early in the interaction process (Fig. 3A). This causes the epidermis to rupture (Fig. 3B), allowing bacteria to exude from lesions. Individual lesions are usually smaller than $0.5 \mathrm{~cm}^{2}$, but they may coalesce to form larger necrotic areas. Several months after infection, leaf lesions dry and turn light brown ash-gray (Fig.
2B). Severe leaf infection may result in abscission; otherwise leaves remain attached. Fruit symptoms appear as small water-soaked spots on lenticels. These spots later become star-shaped, erumpent, and exude an infectious gum (Fig. 4A and B). Often, a "tear stain" infection pattern is observed on the fruit. Severe fruit infections will cause premature fruit drop. Less severe infections reduce fruit quality and allow entry of other pathogens. Twig cankers (Fig. 5) are potential sources of inoculum and weaken branch resistance to winds, but such lesions seem to occur only when climatic events (such as tropical storms) are responsible for massive inoculum redistribution and wounds. The disease is not systemic and does not affect the root
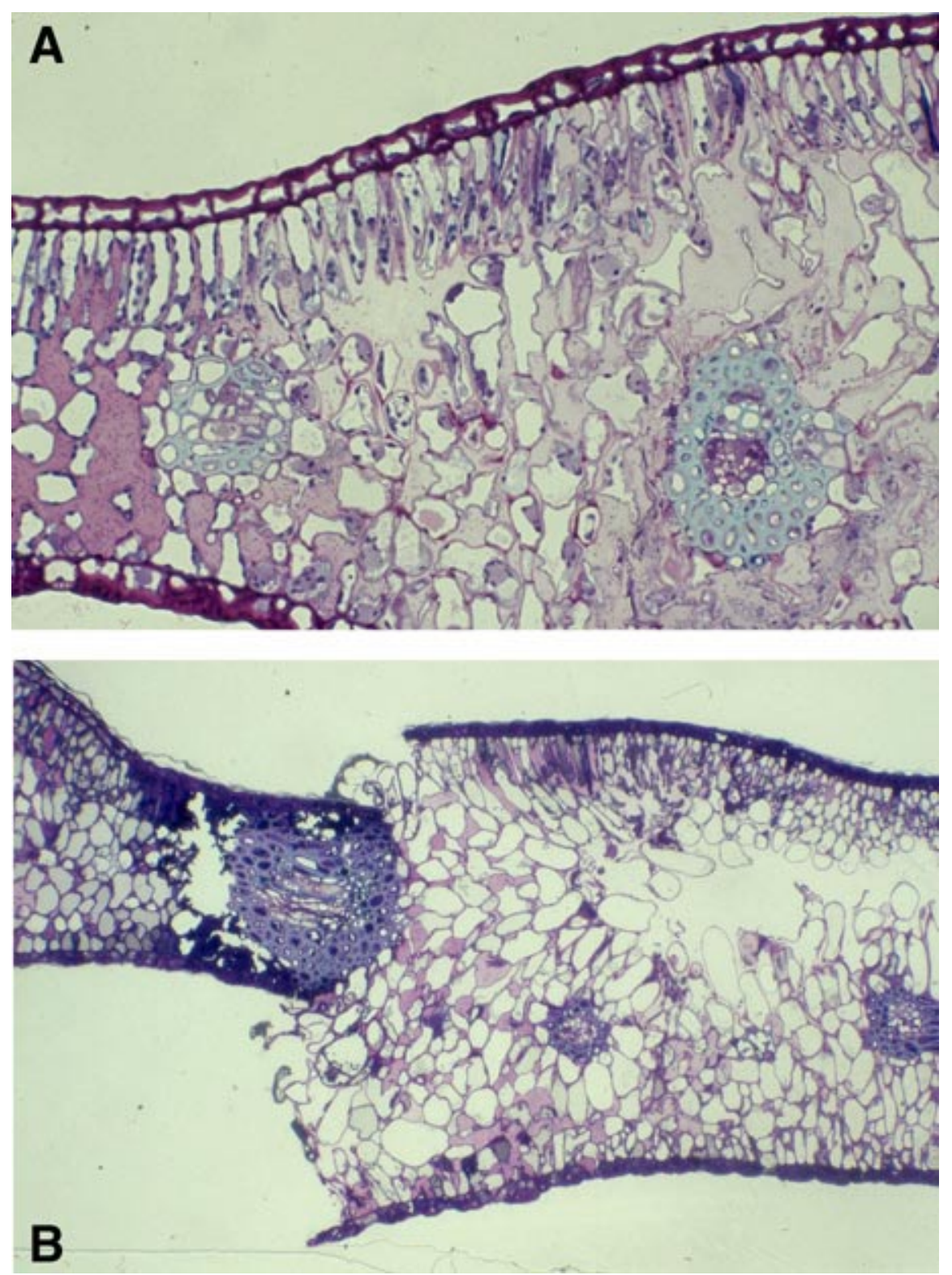

Fig. 3. Sections of mango bacterial black spot (MBBS) leaf lesions observed by light microscopy after toluidine blue staining. A, Ten days after inoculation (with $10^{5}$ CFU/ml), the mesophyll intercellular spaces are enlarged and cells are hypertrophied. Bacteria are located at the margin of the swollen area (in a pink colored matrix). B, Twenty days after inoculation, ruptures in the epidermis are visible at junctions between swollen areas and necrotic areas. 
system. Bud necrosis and inflorescence cankers are rarely observed, and only on highly susceptible cultivars.

Susceptibility of the plant organs varies with time for a given cultivar; young leaves are resistant, likely because they do not have functional stomata (2), but become very susceptible when they enlarge, with lesions appearing just after leaf hardening. Leaf susceptibility then decreases with time. Fruit susceptibility increases over time and is highest during the month preceding harvest. This correlates with maximum receptivity of the lenticels (50).

\section{Causal Agent}

The MBBS bacterium has all the characteristics associated with the genus Xanthomonas (34) except for pigmentation. Unlike most xanthomonads, it produces nonpigmented (creamy white) colonies when cultivated on agar media. A few yellow-pigmented strains have been isolated from mango in Brazil, Florida, South Africa, and Réunion. The relationship of these atypical yellow strains to MBBS will be discussed in more detail in a later section.

The MBBS bacterium was initially classified as $X$. campestris pv. mangiferaeindicae based on the international standards for naming pathovars of phytopathogenic bacteria (14). However, this bacterium has not been included in any recent taxonomic studies. Therefore, it cannot be assigned to any species until taxonomic analyses using a polyphasic approach (primarily based on DNA-DNA hybridization, complemented by data such as comparison of $16 \mathrm{~S}$ ribosomal DNA sequences, DNA fingerprinting, carbon compounds utilization profiles, fatty acid methyl ester profiles, or wholecell protein profiles) are performed $(52,66,67)$.
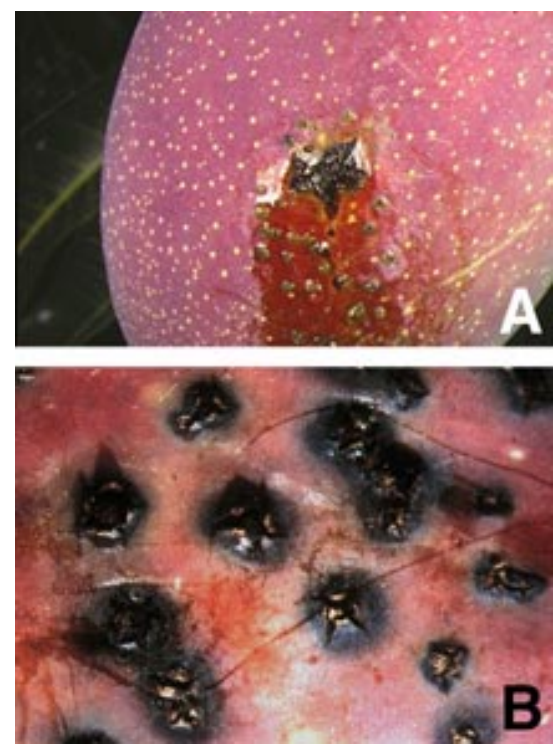

Fig. 4. A, Fruit lesions. B, Crater-like lesions can produce a large amount of gummy exudate, which will cause the infection of other lenticels in the area.
The provisional name we use here is Xanthomonas sp. pv. mangiferaeindicae (65).

\section{Detection}

A semiselective medium has been developed for isolation of the bacterium (56), but it often lacks selectivity against Enterobacteriaceae and other gram-negative bacteria that are common inhabitants of plant surfaces. Polyclonal (51) and monoclonal (57) antibodies have been used to identify the bacterium.

Molecular techniques have also been used to identify $X$. sp. pv. mangiferaeindicae. A DNA probe consisting of almost the entire hypersensitive response and pathogenesis ( $h r p$ ) gene cluster from $X$. oryzae pv. oryzae (35) was used for restriction fragment length polymorphism (RFLP) analysis. Nonpigmented isolates of $X$. sp. pv. mangiferaeindicae collected from mango worldwide (except Brazil) exhibited a single hybridization pattern $(19,48)$. This is consistent with the lack of variability observed in $h r p$-RFLP patterns within pathovars of other bacterial plant pathogens $(3,26,30,58,62)$. Thus, the hrp-RFLP analysis has become a useful technique for identification of $X$. sp. pv. mangiferaeindicae isolates.

\section{Pathogen Diversity}

Diversity within $X$. sp. pv. mangiferaeindicae was initially examined with phenotypic tools, including isoenzymatic variability (60), resistance to antibiotics and heavy metals, and ability to utilize different carbon sources (45). These tests, along with hrp-RFLP analysis, demonstrated a high degree of similarity among nonpigmented $X$. sp. pv. mangiferaeindicae isolates from mango. Genetic variability among $X$. sp. pv. mangiferaeindicae isolates collected from different geographic regions was further studied by using two additional probes for RFLP analysis. They

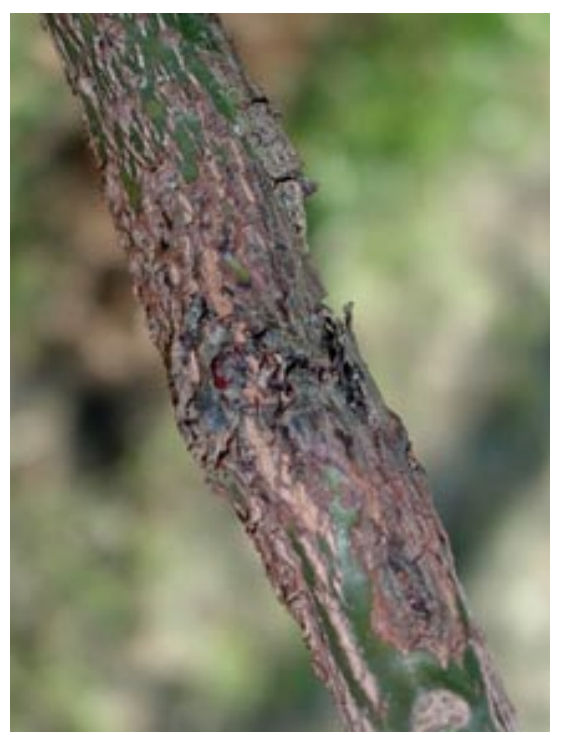

Fig. 5. Wound-associated twig canker. included an avirulence (avr) gene (avrXa10) cloned from $X$. oryzae pv. oryzae (25) and a repetitive insertion sequence (IS) from $X$. sp. pv. mangiferaeindicae (IS1595, Genbank accession no. AF249895). The avrXa10 gene is a member of the $a v r B s 3$ avirulence gene family that is common to different species and pathovars of Xanthomonas (25). The IS from $X$. sp. pv. mangiferaeindicae is not related to a specific family of IS, but is homologous with IS in other pathovars of Xanthomonas (18). The avr and IS probes differentiated the typical, nonpigmented isolates into groups that corresponded to geographic location (19).

Atypical strains, including yellowpigmented strains collected in various countries and the nonpigmented strains isolated from mango in Brazil and from ambarella (Spondias cytherea Sonn.) in the French West Indies had hrp-RFLP hybridization patterns and phenotypical characteristics distinct from the typical mango strains. These strains also did not hybridize with the $a v r$ or IS probes, indicating they were genetically distinct from $X$. sp. pv. mangiferaeindicae. The actual incidence of MBBS in Brazil due to the nonpigmented xanthomonad isolated from mango has never been documented. Yellow-pigmented isolates from mango multiply only weakly in mango parenchyma and are considered casual pathogens (L. Gagnevin and $\mathrm{O}$. Pruvost, unpublished). Casual xanthomonads with or without hrp genes have been described on several other plant species $(4,24,62)$.

\section{Hosts}

Several members of the Anacardiaceae family other than mango have been reported as hosts for $X$. sp. pv. mangiferaeindicae. It was reported from cashew (Anacardium occidentale L.) in India (40), but these strains were not saved. Whitepigmented Xanthomonas strains also have been isolated from ambarella in the French West Indies (54) and from Brazilian pepper (Schinus terebinthifolius Raddi) in Réunion (43).

Ambarella strains (i.e., nonpigmented with $h r p$-RFLP profiles distinct from mango isolates) reduce fruit production and cause a severe dieback on ambarella in Martinique (54). These strains also will induce symptoms on mango following artificial inoculation (49). When aggressiveness of the ambarella strains was quantitatively assessed on mango, bacterial populations in lesions 30 days after infiltration were 100-fold lower than lesions on leaves inoculated with mango strains. Ambarella strains have not been isolated from mango in Martinique, and MBBS has not been reported in this island. Thus, ambarella strains are not only taxonomically distinct from mango isolates, but also are much less aggressive 
on this host. Therfore, Ambarella strains are not a significant threat to mango.

The situation is more complex for $X$. sp. pv. mangiferaeindicae strains from Brazilian pepper. This plant sometimes is used for windbreaks around mango orchards. It also is an invasive weed in many tropical regions. Bacterial isolates from Brazilian pepper cannot be distinguished from mango isolates by most phenotypic and genetic analyses including $h r p$ - and ISRFLP typing. Only DNA hybridization patterns resulting from the avrBs3 genefamily probe were successful in separating Brazilian pepper strains from those from mango (19). When bacterial strains collected from Brazilian pepper and mango growing in close proximity to one another were characterized by avr-RFLP analysis (20), the strains with the Brazilian peppertype DNA fingerprint were only collected from Brazilian pepper, whereas strains with a mango-type fingerprint were only isolated from mango. These results indicated host specificity. Brazilian pepper strains are pathogenic to mango following artificial inoculation (47). However, bacterial populations in mango lesions inoculated with Brazilian pepper strains (following artificial inoculations at $10^{5} \mathrm{CFU} / \mathrm{ml}$ ) were 1 to $1.5 \mathrm{LOG}$ units lower than in lesions inoculated with mango strains (17). The correlation between aggressiveness and $a v r$-RFLP hybridization patterns suggests that these avirulence genes play a role in aggressiveness and host specificity. These results also demonstrate the unlikelihood of Brazilian pepper being a potential reservoir for MBBS.

\section{Survival}

Survival of $X$. sp. pv. mangiferaeindicae is very efficient in leaf lesions. Bacterial populations decrease relatively slowly in leaf lesions on trees maintained under controlled conditions (Fig. 6) (17). Threemonth-old leaf lesions on a susceptible cultivar may contain up to $10^{7} \mathrm{CFU}$, and up to $10^{5} \mathrm{CFU}$ were detected in 18-monthold lesions. Incidence of diseased fruit is highly correlated with leaf spot severity observed 6 months previously (33). Twig cankers also serve as a source of inoculum, but their relative importance compared with bacterial inoculum in leaves is difficult to assess (Fig. 7).

Bacterial populations on mango surfaces can average as high as $10^{6} \mathrm{CFU}$ per leaf or fruit. However, most studies failed to adequately determine whether these populations from apparently healthy tissue were "true" resident epiphytes (sensu Leben [29]), latent infections, or temporary survivors (casuals) on the phyllosphere following rain or irrigation events. Surface populations vary depending on climatic conditions but are correlated to the number of leaf lesions (Fig. 7). The presence of free water allows the release and redistri- bution of bacteria from the ruptured epidermis. Humid conditions are generally favorable to epiphytic survival. Bacterial populations quickly decrease to undetectable levels during dry conditions (44). Approximately $10^{2} \mathrm{CFU}$ were detected in buds 2 weeks after application of a marked strain of $X$. sp. pv. mangiferaeindicae. Following budbreak, populations of approximately $10^{4} \mathrm{CFU}$ were detected on young leaves. After leaf hardening, lesions developed and the marked strain was reisolated from symptomatic tissue (46).

Populations of $10^{4}$ to $10^{6} \mathrm{CFU}$ per fruit can be present on young fruits in natural conditions and probably constitute inoculum associated with latent infections (Fig. 7), which will be responsible for symptoms when the fruit receptivity increases (50). No data so far are supportive of a resident epiphytic phase involving multiplication of the bacterium on the surface of the organs, but there is a clear need for additional data on this topic. $X$. sp. pv. mangiferaeindicae has no significant long-term ability to survive on the ground in dead leaves or in soil (51).

\section{Dissemination}

Large-scale dissemination of the disease probably occurs on contaminated propagating plant material. For instance, identical haplotypes, defined by avr- and IS-RFLP typing, have been found in separate countries such as Mauritius, New Caledonia, South Africa, and Réunion (19). Exchange of plant material among these countries has occurred because of their relatively close proximity and the fact that many of the regions were governed by the same country for most of their recent history. Seed transmission of $X$. sp. pv. mangiferaeindicae has not been demonstrated.
Wind-driven rains are important in local dissemination of bacterial plant pathogens. For citrus canker, caused by Xanthomonas axonopodis pv. citri, a combination of rain and wind speeds of at least $6 \mathrm{~m} \mathrm{~s}^{-1}$ is sufficient to disperse inoculum from tree to tree (59). Higher wind speeds, such as those prevailing during hurricanes, can spread the citrus canker bacterium several miles (21) and can create wounds for infection. For the mango- $X$. sp. pv. mangiferaeindicae pathosystem, emergence of the disease in a healthy susceptible orchard is typically recorded 3 to 4 weeks after the occurrence of similar rain and wind combinations (47).

We studied movement of $X$. sp. pv. mangiferaeindicae in an experimental orchard established with disease-free, susceptible mango trees (18). Shortly after planting, the orchard underwent two minor tropical storms (wind speeds of $24 \mathrm{~m} \mathrm{~s}^{-1}$ and $16 \mathrm{~m} \mathrm{~s}^{-1}$, respectively). Immediately following the storms, MBBS was randomly distributed in the orchard but later acquired an aggregated distribution. Seven hundred bacterial strains were collected from the orchard and were compared with epiphytic stains collected in the nursery and from the budwood trees used for propagation, and with strains collected from lesions on mango trees near the orchard. All strains were typed by RFLP using IS1595 as a probe. Nine haplotypes were recovered from the orchard. Ninetyfour percent of the strains were represented by a single haplotype. This haplotype was also recovered from an infected wild mango growing $250 \mathrm{~m}$ upwind of the orchard. Four percent of the isolates were similar to three haplotypes recovered as epiphytic populations of $X$. sp. pv. mangiferaeindicae from the nursery or on budwood trees. The rest of the haplotypes

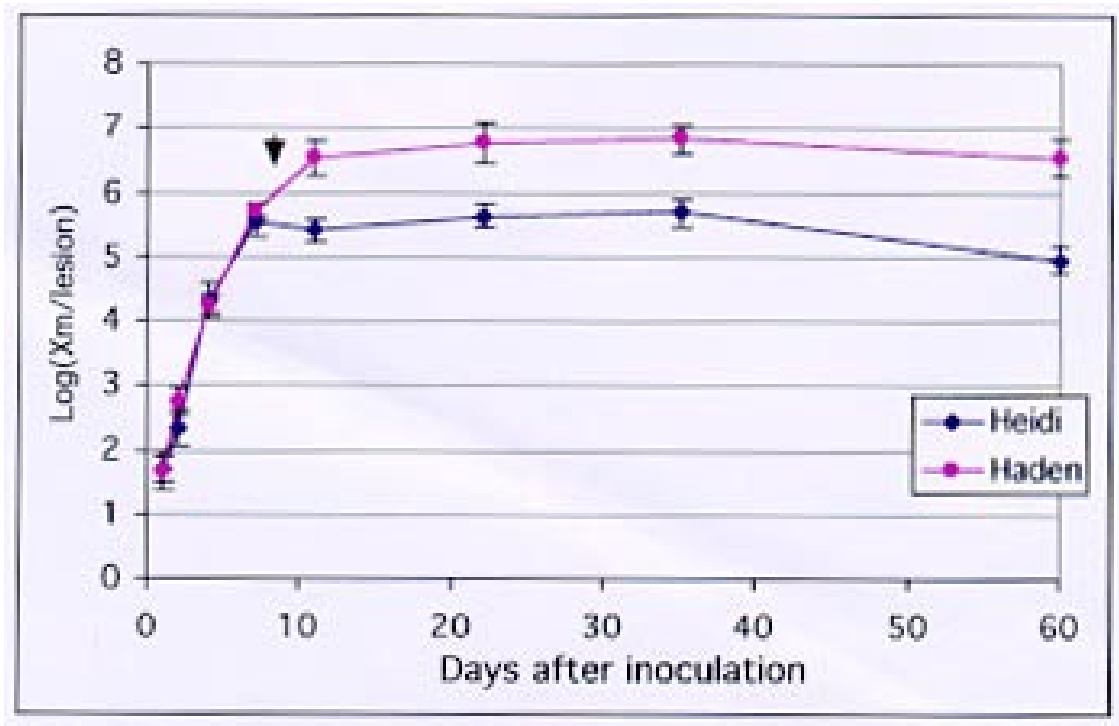

Fig. 6. Bacterial populations in lesions 1 to 60 days after inoculation of a strain from Réunion. Mango leaves were infiltrated with suspensions of $10^{5} \mathrm{CFU} / \mathrm{ml}$. Plants were maintained at $28^{\circ} \mathrm{C}$ with $95 \%$ humidity and a $12-\mathrm{h}$ photoperiod. Haden is a highly susceptible cultivar; Heidi is a partially resistant cultivar. The arrow represents the time when $50 \%$ of the lesions are visible. 
were of unknown origin. In this study, most of the inoculum apparently originated from a nearby infected tree and not from epiphytic populations within the orchard.

The role of insects in the dispersal of $X$. sp. pv. mangiferaeindicae is not known precisely, although some reports suggest it is possible $(28,64)$. Bacterial dissemination within individual trees is primarily caused by splashing of inoculum during rain or irrigation (Fig. 7).

\section{Control}

The production of disease free nursery plant material is an important part of an integrated control scheme. Good nursery practices include disinfection of budwood using bactericides, protection of plants from wind-driven rain by the use of windbreaks, destruction of any potential source of inoculum, and reduction of epiphytic bacterial populations by copper sprays.

Since free water on plant surfaces is a prerequisite to bacterial infection, new

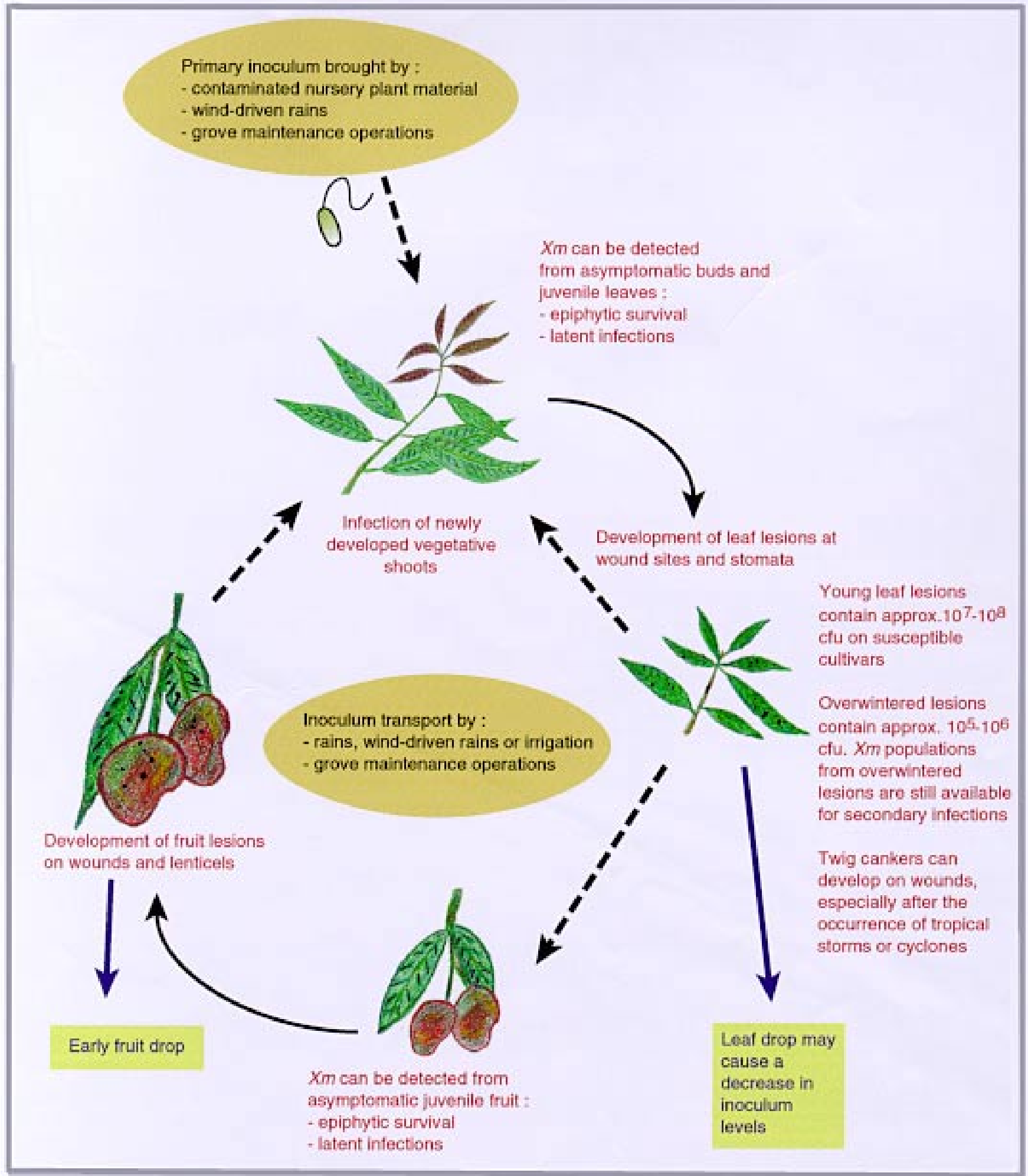

Fig. 7. Epidemiological cycle of mango bacterial black spot (MBBS). Dotted lines represent inoculum redistribution. Solid lines represent the evolution and consequences of the disease on mango organs. 
groves should be established in dry areas. Chemical control of the disease is generally ineffective. Cupric compounds can help to reduce epiphytic inoculum in the absence of lesions but have no curative action. Furthermore, the accumulation of copper in soils following extended use may result in unacceptable long-term consequences. Successful control of MBBS has been achieved by using an integrated approach that includes destroying inoculum sources (pruning), use of appropriate cultural practices (i.e., windbreaks and drip irrigation), and regularly applying copper. In South Africa, more than 20 annual sprays of copper are applied on susceptible cultivars. However, there is increasing concern that this will result in selection of copper resistance in the bacterial populations. Windbreaks have been planted around mango groves to reduce wounds and dissemination of bacteria by winddriven rain. Growers have sometimes placed foam cups over developing fruit to prevent infection from splashing water, but results have been inconsistent (8).

No cultivar with complete resistance to MBBS is available, but disease severity usually is low on partially resistant cultivars such as Heidi and Sensation. Significant differences in susceptibility among cultivars are revealed by measuring $X$. sp. pv. mangiferaeindicae populations in leaf lesions (L. Gagnevin and O. Pruvost, unpublished). Typically, in controlled conditions, a susceptible cultivar such as Haden can host $10^{7}$ to $10^{8} \mathrm{CFU}$ per lesion, while a partially resistant cultivar such as Heidi hosts $10^{6}$ to $10^{7} \mathrm{CFU}$ per lesion (Fig. 6).

We studied the development of MBBS in two neighboring orchards planted at the same time and receiving identical cultural treatments. One of the orchards was composed of a susceptible cultivar (Haden), whereas the other was planted to a partially resistant cultivar (Heidi). Epidemiological data indicated that the epidemics have a classical pattern with an initial random distribution developing into an aggregated distribution. The differences between the two orchards reside in the amount of symptoms per tree and the fact that the course of the epidemic was two times slower in the case of the partially resistant cultivar. Preliminary data on the bacterial diversity analyzed with the avr and IS typing tools indicate that the diversity (calculated with the Shannon index) is significantly lower for strains isolated from the partially resistant cultivar. These results suggest that this partial resistance is responsible for a selection on the population of bacteria that are causing the epidemic. Whether this selection on the bacterial population is continuous over several years of epidemic and whether it is correlated to an increase of bacterial aggressiveness, which would impair the efficiency of the partial resistance, are goals of continued research.
In areas with a late rainy season, the use of early fruiting cultivars allows for healthy crop production. Despite efforts to develop biological control methods, none are currently used to control the disease commercially.

\section{Conclusions}

A prerequisite for an efficient integrated control of MBBS is to have a good knowledge of the biology and ecology of the pathogen, an understanding of the population structure at different spatial and time scales, and a precise knowledge of the different aspects of the epidemiology of the disease. Especially, it is not sufficient to evaluate which parameters are associated with epidemics. The relative weight of different parameters (e.g., inoculum sources, dissemination modes, survival strategies) in different conditions should be assessed.

When studying MBBS, molecular tools have proven to be valuable for answering some of these questions. They allowed us to understand diversity with $X$. sp. pv. mangiferaeindicae and how the different genetic groups are distributed and related. We also were able to clarify the relationship among bacterial strains among members of the Anacardiaceae.

Information obtained from "classical" epidemiological studies can be enhanced by genetic analysis of bacterial strains associated with epidemics. This approach, often referred to as "molecular epidemiology," integrates the genetic diversity of bacterial inoculum, which is no longer regarded as homogenous but as a mixture of interacting subpopulations. The two case studies we described in this paper are examples where molecular epidemiology is a powerful tool for identifying inoculum that results from migration processes and for evaluating how the population structure of a bacterial pathogen evolves in response to selection pressures driven by host populations (or environmental variations).

There is a need to delve further into population structure studies (as well as quantitative epidemiological studies) to improve the current knowledge on the life cycle of $X$. sp. pv. mangiferaeindicae. So far, we used mostly RFLP as the typing technique. However, this technique is too labor consuming for more extensive epidemiological studies, which would involve DNA typing of very large numbers of isolates. The potential value of repeated DNA sequences, such as insertion sequences, for large-scale epidemiological studies should be carefully evaluated using PCR-based techniques and should be compared with that of automated techniques (e.g., fluorescent AFLP). Nevertheless, when using molecular techniques for bacterial epidemiology, one should be careful to understand and make correct assumptions on the correlation between genetic relatedness and epidemiological relatedness of two populations (47).
The current knowledge of the characteristics and the epidemiological significance of epiphytic populations remains largely unknown for $X$. sp. pv. mangiferaeindicae and more generally for members of the genus Xanthomonas. Some studies or reviews suggest that although there is some variation in the ability of xanthomonads to survive on plant surfaces (63), they are generally poor colonizers of the phyllosphere $(55,61)$. Molecular typing can complement classical microbial ecology studies and may help to address some questions on the characteristics of the epiphytic survival of xanthomonads, especially the importance of immigrationemigration processes (32).

The knowledge on the diversity and population structure of $X$. sp. pv. mangiferaeindicae has improved in recent years. More data on the epidemiology of the disease should be obtained in the future. These aspects may efficiently complement breeding programs in order to define guidelines for evaluating new mango lines for susceptibility to MBBS. Also, a better understanding of the genetic diversity of the bacterium will help to construct detection tools that are essential to avoid introduction of the pathogen in areas where it is not already present.

\section{Acknowledgments}

We wish to express our appreciation to V. Glories and A. Couteau for technical assistance. We are thankful to M. Nicole and B. Boher (IRD, France) for microscopic observations and B. Q. Manicom (ARC-ITSC, South Africa) for information on MBBS in the South African mango industry.

\section{Literature Cited}

1. Afzal, M. A. 1987. Outbreaks and new records. Pakistan. Black spot of mango. FAO Plant Prot. Bull. 35:165.

2. Ali, K., Koeda, K., and Nii, N. 1999. Changes in anatomical features, pigment content and photosynthetic activity related to age of 'Irwin' mango leaves. J. Jpn. Soc. Hortic. Sci. 68:1090-1098.

3. Alizadeh, A., Arlat, M., Sarrafi, A., Boucher, C. A., and Barrault, G. 1997. Restriction fragment length polymorphism analyses of Iranian strains of Xanthomonas campestris from cereals and grasses. Plant Dis. 81:31-35.

4. Angeles-Ramos, R., Vidaver, A. K., and Flynn, P. 1991. Characterization of epiphytic Xanthomonas campestris pv. phaseoli and pectolytic xanthomonads recovered from symptomless weeds in the Dominican Republic. Phytopathology 81:677-681.

5. Ann, P. J. 1978. Studies on mango bacterial spot. I. Ecology and disease development Nat. Sci. Counc. Monthly VI:1-21.

6. Anonymous. 2001. Statistics on mango production. FAOSTAT database, published online.

7. Arauz, L. F. 2000. Mango anthracnose: Economic impact and current options for integrated management. Plant Dis. 84:600-611.

8. Boshoff, M., Kotze, J. M., and Korsten, L. 1998. Control of bacterial black spot in mango. S.A. Mango Growers' Assoc. Yrbk. 18:36-39.

9. Buruchara, R. A., Mukunya, D. M., and Gathuru, E. M. 1990. Bacterial black spot of 
mangoes in Kenya. Pages 577-582 in: Int. Conf. Plant Path. Bact. 7th. Budapest, Hungary.

10. Cazorla, F. M., Tores, J. A., Olalla, L., PerezGarcia, A., Farre, J. M., and de Vicente, A. 1998. Bacterial apical necrosis of mango in southern Spain: A disease caused by Pseudomonas syringae pv. syringae. Phytopathology 88:614-620.

11. Daniel, J. F., Gardan, L., Luisetti, J., and Prunier, J. P. 1975. Identification de l'agent responsable de la maladie des taches noires de la mangue (Mangifera indica). Fruits 30:625630.

12. Dodd, J. C., Prusky, D., and Jeffries, P. 1997. Fruit diseases. Pages 257-291 in: The mango: Botany, production and uses. R. E. Litz, ed. CAB International, Oxon, NY.

13. Doidge, E. M. 1915. A bacterial disease of the mango. Bacillus mangiferae n. sp. Ann. Appl. Biol. II:1-44.

14. Dye, D. W., Bradbury, J. F., Goto, M., Hayward, A. C., Lelliott, R. A., and Schroth, M. N. 1980. International standards for naming pathovars of phytopathogenic bacteria and a list of pathovar names and pathotype strains. Rev. Plant Pathol. 59:153-168.

15. El Goorani, M. A. 1987. Plant diseases caused by bacteria in United Arab Emirates. Pages 653-657 in: Int. Conf. Plant Path. Bact. 6th. College Park, MD.

16. Fukuda, T., Uehara, K., Azegami, K., Tabei, H., and Nishiyama, K. 1990. Bacterial canker of Mango in Japan caused by Xanthomonas campestris pv. mangiferaeindicae. Ann. Phytopathol. Soc. Jpn. 56:474-480.

17. Gagnevin, L. 1998. Analyse de la diversité génétique de Xanthomonas pv. mangiferaeindicae et sa signification dans le pouvoir pathogène et la biologie de la bactérie. Implications dans l'épidémiologie de la maladie des taches noires du manguier à l'île de la Réunion. Ph.D., INA P-G, Paris, France.

18. Gagnevin, L., Bouvet, G., Mete, K., Manceau, C., and Pruvost, O. 2000. Interest of the insertion sequence IS1595 as a population typing tool for Xanthomonas pv. Mangiferaeindicae. Congr. Eur. Foundation Plant Pathol. 5th. Taormina - Giardini Naxos, Italy.

19. Gagnevin, L., Leach, J. E., and Pruvost, O. 1997. Genomic variability of the Xanthomonas pathovar mangiferaeindicae, agent of mango bacterial black spot. Appl. Environ. Microbiol. 63:246-253.

20. Gagnevin, L., and Pruvost, O. 1998. Assessment by RFLP analysis of the population structure of Xanthomonas pathovar mangiferaeindicae with a single field containing two host species. Pages 2-2-36 in: Int. Congr. Plant Pathol. 7th. Edinburgh, UK

21. Gottwald, T. R., Graham, J. H., and Schubert, T. S. 1997. An epidemiological analysis of the spread of citrus canker in urban Miami, Florida, and synergistic interaction with the Asian citrus leafminer. Fruits 52:383-390.

22. Guevara, Y. M., Rondon, A., Arnal, E., and Solorzano, R. 1985. Bacteriosis del mango (Mangifera indica L.) en Venezuela. II. Distribucion, perpetuacion, diseminacion $\mathrm{y}$ evaluacion de la resistencia de variedades. Agron. Trop. (Venezuela) 35:63-75.

23. Guevara, Y. M., Rondon, A. G., and Solorzano, R. 1980. Bacteriosis del mango (Mangifera indica L.) en Venezuela. I. Sintomatologia e identificacion. Agron. Trop. (Venezuela) 30:65-76

24. Hartung, J. S., and Civerolo, E. L. 1991. Variation among strains of Xanthomonas campestris causing citrus bacterial spot. Plant Dis. 75:622-626

25. Hopkins, C. M., White, F. F., Choi, S. H., Guo, A., and Leach, J. E. 1992. Identification of a family of avirulence genes from Xantho-

monas oryzae pv. oryzae. Mol. Plant-Microbe Interact. 5:451-459.

26. Kanamori, H., Sugimoto, H., Ochiai, H., Kaku, H., and Tsuyumu, S. 1999. Isolation of hrp cluster from Xanthomonas campestris pv. citri and its application for RFLP analyses of xanthomonads. Ann. Phytopathol. Soc. Jpn. 65:110-115.

27. Kishun, R. 1982. Loss in mango fruit due to bacterial canker Xanthomonas mangiferaeindicae. Pages 181-184 in: Int. Conf. Plant Path. Bact. 5th. Cali, Colombia.

28. Kishun, R. 1986. Role of insects in transmission and survival of Xanthomonas campestris pv. mangiferaeindicae. Ind. Phytopathol. 39:509-511.

29. Leben, C. 1965. Epiphytic microorganisms in relation to plant disease. Annu. Rev. Phytopathol. 3:209-230.

30. Legard, D. E., Aquadro, C. F., and Hunter, J. E. 1993. DNA sequence variation and phylogenetic relationships among strains of Pseudomonas syringae pv. syringae inferred from restriction site maps and restriction fragment length polymorphism. Appl. Environ. Microbiol. 59:4180-4188.

31. Lim, T. K., Sijam, K., and Ong, E. T. 1991. Bacterial black spot of Mango. A new disease in Malaysia. Acta Hortic. 291:317-323.

32. Lindow, S. E., and Andersen, G. L. 1996. Influence of immigration on epiphytic bacterial populations on navel orange leaves. Appl. Environ. Microbiol. 62:2978-2987.

33. Manicom, B. Q. 1986. Factors affecting bacterial black spot of mangoes caused by Xanthomonas campestris pv. mangiferaeindicae. Ann. Appl. Biol. 109:129-135.

34. Manicom, B. Q., and Wallis, F. M. 1984. Further characterization of Xanthomonas

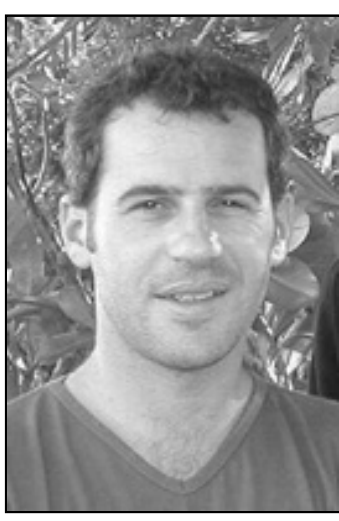

Lionel Gagnevin

Dr. Gagnevin received his Ph.D. in plant pathology at Institut National Agronomique, Paris, France, on the genetic diversity and pathogenicity of the agent of mango black spot. He was hired at CIRAD in 1998 to work on the molecular variability and population structure of several xanthomonads, especially in relation with the epidemiology of bacterial diseases on tropical plants. campestris pv. mangiferaeindicae. Int. J. Syst. Bacteriol. 34:77-79.

35. Mazzola, M., White, F. F., and Leach, J. E. 1992. Identification and partial characterization of a hrp gene cluster from Xanthomonas oryzae pv. oryzae. (Abstr.) Phytopathology $82: 1125$

36. McMillan, R. T., and Wang, A. 1992. A new disease of mango in Costa Rica caused by Erwinia-like bacteria. Proc. Fla. State Hortic. Soc. 105:288-289.

37. Moffett, M. L., Peterson, R. A., and Wood, B. A. 1979. Bacterial black spot of mango. Australas. Plant Pathol. 8:54-56.

38. Moll, J. 1985. Mango wilt in Israel and Florida. CSFRI Inf. Bull. 149:10.

39. Mukherjee, S. K. 1997. Introduction: Botany and importance. Pages 1-21 in: The Mango: Botany, Production and Uses. R. E. Litz, ed CAB International, Oxon, NY.

40. Patel, M. K., Kulkarni, Y. S., and Moniz, L. 1948. Pseudomonas mangiferae-indicae, pathogenic on mango. Ind. Phytopathol. $1: 147-152$.

41. Ploetz, R. C., and Prakash, O. 1997. Foliar, floral and soilborne diseases. Pages 281-327 in: The Mango: Botany, Production and Uses. R. E. Litz, ed. CAB International, Oxon, NY.

42. Prakash, O., and Misra, A. K. 1992. Important diseases of mango and their effect on production. Biol. Memoirs 18:39-55.

43. Pruvost, O., Couteau, A., and Luisetti, J. 1992. Pepper tree (Schinus terebenthifolius Radii), a new host plant for Xanthomonas campestris pv. mangiferaeindicae. J. Phytopathol. 135:289-298.

44. Pruvost, O., Couteau, A., Luisetti, J., and Vernière, C. 1995. Biologie et épidémiologie de l'agent de la maladie des taches noires de 
la mangue. Fruits 50:183-189.

45. Pruvost, O., Couteau, A., Perrier, X., and Luisetti, J. 1998. Phenotypic diversity of Xanthomonas sp. mangiferaeindicae. J. Appl. Microbiol. 84:15-24.

46. Pruvost, O., Couteau, A., Vernière, C., and Luisetti, J. 1993. Epiphytic survival of Xanthomonas campestris pv. mangiferaeindicae on mango buds. Acta Hortic. 341:337-344.

47. Pruvost, O., and Gagnevin, L. 2001. Population structure of xanthomonads with endophytic and epiphytic phases: The example of the pathovar mangiferaeindicae/mango pathosystem. Phyllosphere Microbiology. S. Lindow, ed., American Phytopathological Society, St. Paul, MN. In press.

48. Pruvost, O., Gagnevin, L., Glories, V., Couteau, A., Some, A., and Samson, R. 2000. Phenotypic and genetic diversity of xanthomonads associated with Anacardiaceae. Acta Hortic. 509:793-801.

49. Pruvost, O., and Luisetti, J. 1989. Strains of Xanthomonas campestris isolated from Ambarella (Spondias cytherea Sonn.) in the French West Indies belong to pv. mangiferaeindicae. (Abstr.) Phytopathology 79:1191.

50. Pruvost, O., and Luisetti, J. 1991. Effect of time of inoculation with Xanthomonas campestris pv. mangiferaeindicae on mango fruits susceptibility. Epiphytic survival of $X$. $c$. pv. mangiferaeindicae on mango fruits in relation to disease development. J. Phytopathol. 133:139-151.

51. Pruvost, O., and Manicom, B. Q. 1993. Xanthomonas campestris pv. mangiferaeindicae: Cause of bacterial black spot of mangoes. Pages 91-95 in: Xanthomonas. J. G. Swings and E. L. Civerolo, eds. Chapman \& Hall, London.

52. Rademaker, J. L. W., Hoste, B., Louws, F. J., Kersters, K., Swings, J., Vauterin, L., Vauterin, P., and De Bruijn, F. J. 2000. Comparison of AFLP and rep-PCR genomic fingerprinting with DNA-DNA homology studies: Xanthomonas as a model system. Int. J. Syst. Evol. Microbiol. 50:665-677.

53. Robbs, C. F. 1954. Bacterias fitopatogenicas do Brasil. Agronomia 13:265-282.

54. Rott, P., and Frossard, P. 1986. Un chancre bactérien du Prunier de Cythère (Spondias cytherea, Sonn.) en Martinique. Fruits 41:605-613.

55. Rudolph, K. 1993. Infection of the plant by Xanthomonas. Pages 193-264 in: Xanthomonas. J. G. Swings and E. L. Civerolo, eds. Chapman \& Hall, London.

56. Sanders, G. M., and Korsten, L. 1995. A rapid method for differentiation of Xanthomonas campestris pv. mangiferaeindicae from other xanthomonads and mango phylloplane inhabitants. J. Basic Microbiol. 35:337-347.

57. Sanders, G. M., Verschoor, J. A., Vanwyngaard, S., Korsten, L., and Kotze, J. M. 1994. Production of monoclonal antibodies against Xanthomonas campestris pv. mangiferaeindicae and their use to investigate differences in virulence. J. Appl. Bacteriol. 77:509-518.

58. Scholz, B. K., Jakobek, J. L., and Lindgren, P. B. 1994. Restriction fragment length polymorphism evidence for genetic homology within a pathovar of Pseudomonas syringae. Appl. Environ. Microbiol. 60:1093-1100.

59. Serizawa, S., Inoue, K., and Goto, M. 1969. Studies on citrus canker disease. I. Dispersal of the citrus canker organism. Bull. Fac. Ag ric. Shizuoka Univ. 8:81-85.

60. Somé, A., and Samson, R. 1996. Isoenzyme diversity in Xanthomonas campestris pv. mangiferaeindicae. Plant Pathol. 45:426431.

61. Stall, R. E., Gottwald, T. R., Koizumi, M., and Schaad, N. C. 1993. Ecology of plant pathogenic xanthomonads. Pages 265-299 in: Xan thomonas. J. G. Swings and E. L. Civerolo, eds. Chapman \& Hall, London.

62. Stall, R. E., and Minsavage, G. V. 1990. The use of hrp genes to identify opportunistic xanthomonads. Pages 369-374 in: Int. Conf. Plant Path. Bact. 7th. Budapest, Hungary.

63. Timmer, L. W., Marois, J. J., and Achor, D. 1987. Growth and survival of xanthomonads under conditions nonconducive to disease development. Phytopathology 77:1341-1345.

64. Van Zyl, E., Kotze, J. M., and Steyn, P. L. 1988. Isolation of Xanthomonas campestris pv. mangiferaeindicae from gall fly-induced lesions on mango leaves. Phytophylactica 20:89-90.

65. Vauterin, L., Hoste, B., Kersters, K., and Swings, J. 1995. Reclassification of Xanthomonas. Int. J. Syst. Bacteriol. 45:472-489.

66. Vauterin, L., Rademaker, J., and Swings, J. 2000. Synopsis on the taxonomy of the genus Xanthomonas. Phytopathology 90:677-682.

67. Vauterin, L., Swings, J., Gillis, M., Kersters, K., Mew, T. W., Schroth, M. N., Palleroni, N. J., Hildebrand, D. C., Stead, D. E., Civerolo, E. L., Hayward, A. C., Maraite, H., Stall, R. E., Vidaver, A. K., and Bradbury, J. F. 1990 Towards an improved taxonomy of Xanthomonas. Int. J. Syst. Bacteriol. 40:312-316. 